Уипурене Айсте Барбора

д-р пед. наук, преподаватель

Юргелайтис Вилюс

магистрант

Литовский университет спорта

г. Каунас, Литовская Республика

DOI $10.21661 / r-508096$

\title{
COMPETENCES OF PHYSICAL EDUCATION TEACHERS IN THE SPORTS INJURIES PREVENTION
}

Аннотация: школа-это место, где дети проводят большую часть своего времени. Таким образом, особенно важно удостовериться в том, что они находятся в здоровой и безопасной образовательной среде. Довольно часто дети получают травмьл во время занятий физкультурой. Рассматривая проблему детского травматизма на уроках физкультуры, важно изучить его распространенность, проанализировать причины травматизма на уроках физкультуры с изелью его профилактики или уменьшения таких случаев. Исследование компетентности учителей физической культуры в профилактике спортивного травматизма по-прежнему является малоизученным вопросом. Цель исследования-выявление компетенциий учителей физической культуры по профилактике спортивного травматизма. С помощьью опроса мы выяснили, что учителя физической культуры уделяют внимание разминке и правильным упражнениям на уроке физкультуры. Учащуиеся редко получают травмы на уроках этих учителей физической культуры. Исследование показало, что компетенции опрошенных учителей физической культуры являются высокими.

Ключевые слова: учитель, компетенции, фоизическая культура, травматизм, профилактика травматизма.

Abstract: school is a place where children spend most of their time. Thus, it is particularly important to ensure that it has a healthy and safe learning environment. Quite often, children experience injuries during physical education classes. 
Considering to the problem of children injuries in physical education classes, it is important to examine their prevalence, to analyze the causes of injury in physical education classes to prevent or reduce them. There is still a lack of research on the competence of physical education teachers in the prevention of sports injuries. Research aim - to identify the competenes of physical education teachers for the sports injuries prevention. Using the questionnaire survey we investigated that physical education teachers pay attention to the warm-up and correct exercise in the physical education lesson. Students are rarely injured in the lessons of these physical education teachers. The research showed that competencies of surveyed physical education teachers are high.

Keywords: teacher, competencies, physical education, injuries, prevention.

\section{Introduction.}

Health is important for the well-being of individuals and society, and a healthy population is also a prerequisite for economic productivity and well-being (Collard et al., 2010). Children are an important part of society and their health maintaining and preserving is an important challenge for society. Each major injury of children is associated with major psychological and social problems, economic factors (Carmeli et al., 2003). Children's health is endangered by injury in the school surrounding. One fifth of all children injuries occur in the school surrounding (Strukcinskiene et al., 2015). School is a place where children spend most of their time. Thus, it is particularly important to ensure that it has a healthy and safe learner environment (Collard et al., 2010). Quite often, children experience injuries during physical education classes. According to the research, students usually injure themselves in physical education classes (68 percent) (Strukcinskiene et al., 2015). Thus, sports activities in physical education classes are accompanied by dangers and risks. Although no one teacher wants students to be traumatized during physical education classes, but they nonetheless occur. Injuries sustained during physical education classes can have negative effects on a child's health or even life, therefore it is necessary to carry out effective prevention of injuries and to take advantage of op portunities to reduce the likelihood of injury in 
physical education classes. The head of the school and teachers are responsible for creating a safe and healthy environment in the school and ensuring the safety of the pupil in accordance with the provisions of this law. Considering to the problem of children injuries in physical education classes, it is important to examine their prevalence, to analyze the causes of injury in physical education classes to prevent or reduce them. There is still a lack of research on the competence of physical education teachers in the prevention of sports injuries.

Research aim - to identify the competences of physical education teachers for the sports injuries prevention.

Methods.

The pilot research involved 10 teachers of physical education. The competences of physical education teachers were investigated with the questionnaire which consisted from 19 statements (Collard et al., 2010; Strukcinskiene et al., 2015; Vercruysse et al., 2016). Answering to each statement, the respondents had to choose the variants of their answers by using a 5-point Likert-type scale from 1 to 5 where 1 means «absolutely no» and 5 - «absolutely yes». The arithmetic mean $(\bar{x})$ and standard deviation (SD) of statements amount in each sub-scale were calculated.

Results.

Analyzing physical education teachers' responses to the statements, four statements were found to be most pronounced: «Organizing sessions in smaller groups the possibility of injury in physical education classes would be lower» - 4.00 (1.25) points, «I constantly emphasize why it is important to do warming-up exercises»-4.70(0.48) points, «I am willing to answer any student questions related to injury prevention»$4.70(0.48)$ points, «Ioften give examples why injuries prevention is important» -4.70 (0.48) points.

Physical education teachers agree the least with these statements: «Students are often traumatized during my physical education classes»-1.40(0.52) points, «Students often get complex traumas during my physical education classes»- 1.30(0.48) points, «Students often get sprains during my physical education classes»- 1.60(0.97) points.

Conclusions. 
Summarizing the results, it can be stated that the surveyed physical education teachers pay attention to the warm-up and correct exercise in the physical education lesson. Students are rarely injured in the lessons of these physical education teachers. The research showed that competencies of surveyed physical education teachers are high.

\section{Списоклитературы}

1. Carmeli E., Azencot S., Wertheim M., Coleman R. Sports injuries in students aged 12-18 during physical education classes in Israel // Biology of sports - $2003-$ Volume 20 - P. 272-280.

2. Collard DCM., Verhagen EALM., Chinapaw MJM., Knol DL., van Mechelen W. Effectiveness of a School-Based Physical Activity Injury Prevention Program: A Cluster Randomized Controlled Trial // International Journal of Behavioral Nutrition and Physical Activity - 2010 - Volume 164 - P. 145-150.

3. Strukcinskiene B., Strazdiene N., Norkiene S., Strukcinskaite V. Sport injuries in school children during physical education classes and their prevention // Public Health - 2015 - Volume 6 - P. 56-59.

4. Vercruysse S., Haerens L., Verhagen E., Goossens L., Clercq D. Effects of a multifactorial injury prevention intervention in physical education teachers: A randomized controlled trial // European Journal of Sport Science - 2016 - Volume 16 P. 868-876. 